\title{
Keanekaragaman dan pola keberadaan lalat buah (Diptera: Tephritidae) di Provinsi Sumatera Selatan
}

\author{
Identification of fruit flies (Diptera: Tephritidae) dan \\ their distribution in South Sumatera Province
}

\author{
Yulia Pujiastuti ${ }^{{ }^{*}}$, Chandra Irsan ${ }^{1}$, Siti Herlinda ${ }^{1}$, Laila Kartini ${ }^{2}$, Eka Yulistin ${ }^{2}$ \\ ${ }^{1}$ Program Studi Proteksi Tanaman, Fakultas Pertanian, Universitas Sriwijaya \\ Jalan Palembang-Prabumulih, Km. 32, Indralaya Ogan Ilir, Sumatera Selatan 30662 \\ ${ }^{2}$ Balai Karantina Pertanian Kelas I Boom Baru Palembang \\ Jalan Kol. H. Burlian, Km. 5,5, Palembang 30153
}

(diterima Juli 2020, disetujui November 2020)

\begin{abstract}
ABSTRAK
Lalat buah menyerang sebagian besar tanaman buah sayuran maupun buah konsumsi. Gejala kerusakan berupa pembusukan pada buah yang menyebabkan gugurnya buah. Data tentang keanekaragaman spesies lalat buah di Sumatera Selatan dan pola keberadaannya belum banyak dilaporkan. Tujuan penelitian untuk mempelajari keanekaragaman dan pola keberadaan lalat buah berdasarkan inang dan perangkap. Penelitian dilaksanakan dengan metode survei di 9 kota dan kabupaten di Provinsi Sumatera Selatan. Lalat buah dikoleksi dengan cara mengumpulkan buah yang terserang dan menggunakan perangkap yang mengandung metil eugenol (ME) dan cue lure (CL). Jenis tanaman yang diamati sebanyak 24 jenis, meliputi tanaman buah, sayur dan buah konsumsi. Identifikasi lalat buah dilakukan dengan mengamati karakteristik morfologi luar. Hasil identifikasi lalat buah diperoleh sebanyak 18 spesies dengan perincian 10 spesies dari perangkap CL dan 7 spesies dari perangkap ME. Satu spesies (Bactrocera latrifons) tidak dapat diperangkap baik dengan CL maupun ME. Dari sejumlah 18 spesies tersebut, 7 di antaranya diperoleh dari koleksi buah, yaitu B. albistrigata, B. carambolae, B. fuscitibia, B. occipitalis, B. latrifons, B. papayae, dan Bactrocera sp. Jenis atraktan mempengaruhi keanekaragaman spesies dan jumlah lalat buah yang tertangkap. B. latifrons hanya ditemukan pada pemeliharaan buah koleksi saja. Ketinggian lokasi daerah pengamatan, mempengaruhi keanekaragaman lalat buah. Semua spesies ditemukan di dataran rendah, kecuali B. ascitus, B. cilifera, dan B. latrifons. Di dataran sedang dan tinggi, jumlah spesies lalat buah yang ditemukan lebih sedikit dibandingkan dengan di dataran rendah.
\end{abstract}

Kata kunci: feromon, identifikasi, lalat buah, taksonomi

\begin{abstract}
Fruit flies attack mostly on fruit vegetables and fresh consumed fruit. Symptoms of damage is decaying of fruit surface resulting to fruit falling. Data on the diversity of fruit fly species in South Sumatra and their patterns of presence have not been widely reported. The aim of the research was to study diversity and presence patterns of fruit flies based on the host and trap. The research was conducted using a survey method in 9 cities and districts in South Sumatra Province. Fruit flies were collected by collecting infected fruit and using traps containing cue lure (CL) and methyl eugenol (ME). There were 24 types of plants observed, including fruit, vegetables, and fruit for consumption. Fruit flies identification was carried out by observing external morphological characteristics. The identification resulted 18 species in which CL and ME trap 10 and 7 species, respectively. One

\footnotetext{
*Penulis korespondensi: Yulia Pujiastuti. Program Studi Proteksi Tanaman Fakultas Pertanian Universitas Sriwijaya, Jalan Palembang-
} Prabumulih, Km. 32, Indralaya Ogan Ilir, Sumatera Selatan 30662, Tel: 0711-580663, Faks: 0711-580276, Email: ypujiastuti@unsri.ac.id
\end{abstract}


species (Bactrocera latrifons) did not trapped in both traps. Among 18 species, 7 of them were obtained from fruit collections. The type of attractant affected species diversity and number of fruit flies caught. B. latifrons was only found in fruit rearing. The altitude of observation area affected fruit flies diversity. All species were found in the lowlands, except $B$. ascitus, B. cilifera, and $B$. latrifons. In the moderate lands and highlands, the number of fruit fly species found was less than in the lowlands.

Key words: fruit flies, identification, pheromone, taxonomy

\section{PENDAHULUAN}

Lalat buah merupakan salah satu hama utama pada berbagai tanaman buah, baik buah sayur maupun buah konsumsi (Leblanc et al. 2013; Vargas et al. 2015; Liu et al. 2019). Larva dalam buah menyebabkan buah menjadi busuk dan tidak layak dikonsumsi. Gejala awal kerusakan buah akibat serangan lalat buah berupa adanya bintik hitam pada kulit buah akibat tusukan ovipositor lalat betina sewaktu meletakkan telur (Sohrab et al. 2018). Setelah telur diletakkan, larva akan menetas dan hidup di dalam buah tersebut sampai menjelang masa berkepompong. Oleh karena itu, seringkali menemukan adanya buah rontok karena busuk dengan beberapa larva instar tua pada buah tersebut. Saat menjelang berkepompong, lalat buah akan keluar dengan cara melentingkan diri dan jatuh ke permukaan tanah untuk berkepompong. Selanjutnya, kepompong akan berada di dalam tanah selama 9-10 hari (Liu et al. 2019) dan akan menetas menjadi lalat buah dewasa.

Pada umumnya, lalat jantan tertarik pada metil eugenol yang dihasilkan oleh tanaman dan bersifat sebagai "food lure" (Kardinan 2019). Dalam tubuhnya, lalat jantan mengubah metil eugenol tersebut menjadi senyawa pheylpropanoid dan coniferyl alcohol, yang pada akhirnya berfungsi sebagai sex feromon untuk menarik serangga betina (Vargas et al. 2000). Oleh karena itu, penggunaan metil eugenol menjadi lazim digunakan untuk memerangkap lalat buah jantan baik untuk tujuan survei maupun pengendalian (Tan et al. 2014; Shelly 2010; Shelly et al. 2014; Kardinan 2019).

Saat ini, di seluruh dunia terdapat lebih kurang 4.000 spesies Tephritidae dari 500 genus, 160 genus di antaranya ditemukan di Asia (Siwi et al. 2006), sedangkan di Indonesia telah diketahui dan diidentifikasi spesies lalat buah sebanyak 63 spesies (AQIS 2008). Di Sumatera Selatan, penelitian tentang keberadaan lalat buah sudah dilakukan selama dua dekade dan menghasilkan banyak karya dalam penelitian skripsi dan tesis. Namun, secara khusus untuk identifikasi belum pernah dilaporkan. Tujuan penelitian untuk mempelajari keanekaragaman dan pola keberadaan lalat buah berdasarkan inang dan perangkap.

\section{BAHAN DAN METODE}

\section{Sampling buah terserang}

Sampling buah dilakukan di 9 kabupaten dan kota di Provinsi Sumatera Selatan dan berdasarkan ketinggian tempat, yaitu 1) dataran rendah (0-100 $\mathrm{m} \mathrm{dpl}$; 2) dataran sedang (400-600 m dpl); 3) dataran tinggi (750-1.300 m dpl) (Tabel 1). Buah yang diambil adalah buah terserang dengan gejala serangan berupa bintik-bintik hitam bekas tusukan ovipositor. Pengambilan sampel buah dilakukan di kebun buah dalam kurun waktu satu tahun dari bulan April 2018 sampai dengan Maret 2019. Buah sampel dimasukkan ke dalam kantong yang diberi label lokasi, jenis buah, dan tanggal pengambilan.

\section{Pemeliharaan lalat buah}

Buah diletakkan dalam wadah pemeliharaan yang telah diberi pasir steril pada bagian dasarnya. Peletakan buah dipisahkan berdasarkan jenisnya. Bagian tutup wadah pemeliharaan tersebut dilubangi dan selanjutnya lubang ditutup dengan kain kasa agar aerasi udara terjaga. Larva akan keluar dari buah untuk berpupa di dalam pasir. Setelah terbentuk pupa sempurna, pupa diambil secara hati-hati dan dipindahkan ke dalam wadah pemeliharaan yang lain. Imago yang muncul dari pupa diberi pakan larutan madu 10\% pada kertas tisu yang lembab. Setelah perkembangan sempurna, imago dimatikan dengan cara pendinginan selama 30 menit di dalam refrigerator. Imago lalat buah dikoleksi secara kering dengan menggunakan micropin dan siap untuk diidentifikasi. 
Sampling dengan perangkap metil eugenol (ME) dan cue lure (CL)

Perangkap yang digunakan adalah modifikasi Steiner tipe dua dengan atraktan berupa ME dan CL (Gambar 1). Perangkap dipasang di kebun buahbuahan dengan cara digantung dengan ketinggian minimal 0,5 $\mathrm{m}$ di bawah tajuk tanaman yang tidak terlalu rimbun. Pemasangan perangkap dilakukan pada pagi hari dalam keadaan cuaca cerah dan tidak hujan. Setelah 24 jam, perangkap diambil. Lalat buah yang terperangkap dimasukkan dalam botol vial, dan diberi label data tanggal, lokasi, jenis atraktan, dan habitat. Imago yang didapat selanjutnya dikoleksi untuk proses identifikasi.

\section{Identifikasi morfologi lalat buah}

Identifikasi dilaksanakan di Laboratorium Entomologi, Balai Karantina Tumbuhan Kelas
I Boom Baru Palembang; dan Laboratorium Entomologi, Program Studi Proteksi Tanaman, Fakultas Pertanian, Universitas Sriwijaya, dengan menggunakan mikroskop stereo Nikon SMZ 1000 dan mikroskop binokuler Olympus SZ2-ILST. Identifikasi spesies lalat buah dilakukan berdasarkan ciri-ciri morfologi penting yang umum digunakan untuk identifikasi. Bagian-bagian yang penting itu antara lain bentuk pola warna gelap pada wajah, warna skutum antara hitam dengan coklat kemerahan, bentuk dan panjang lateral postsutural vittae, lebar mesopleural stripe, variasi warna pada tungkai dan spot hitam di femur, ukuran costal band pada sayap serta variasi warna pada abdomen terga III-V. Identifikasi menggunakan beberapa kunci di antaranya ditulis Drew (1989), Drew \& Hancock (1994), Siwi et al. (2006), Suputa et al. (2006) dan kunci elektronik LUCID.

Tabel 1. Lokasi sampling di sentra buah-buahan dan sayuran pada berbagai ketinggian tempat di Sumatera Selatan

\begin{tabular}{|c|c|c|c|c|c|}
\hline No & Desa & Kecamatan & $\begin{array}{c}\text { Kota/ } \\
\text { Kabupaten }\end{array}$ & $\begin{array}{l}\text { Altitude } \\
\text { (m dpl) }\end{array}$ & Koordinat \\
\hline 1. & Talang Buruk & Alang-alang Lebar & Palembang & 10 & 0294'99.97 LS; 104070’74.17 BT \\
\hline 2. & Sembawa & Banyuasin III & Banyu Asin & 21 & $02^{\circ} 90^{\prime} 83.85 \mathrm{LS} ; 104^{0} 52^{\prime} 95.72 \mathrm{BT}$ \\
\hline 3. & Payaraman & Payaraman & Ogan Ilir & 35 & $03^{\circ} 41^{\prime} 04.67 \mathrm{LS} ; 104^{\circ} 52^{\prime} 88.83 \mathrm{BT}$ \\
\hline 4. & Tanjung Rambang & Ranbang KapakTengah & Prabumulih & 46 & $03^{0} 54^{\prime} 69.00 \mathrm{LS} ; 1^{\circ} 4^{0} 26^{\prime} 33.39 \mathrm{BT}$ \\
\hline 5. & Durian & Peninjauan & OKU Induk & 56 & $03^{\circ} 93^{\prime} 18.81 \mathrm{LS} ; 1^{0} 4^{0} 32^{\prime} 13.10 \mathrm{BT}$ \\
\hline 6. & Sukabumi & Cempaka & OKU Timur & 41 & $03^{\circ} 68^{\prime} 78.90 \mathrm{LS} ; 104^{\circ} 69^{\prime} 35.60 \mathrm{BT}$ \\
\hline 7. & Tanjung Raya & Kota Agung & Lahat & 415 & $03^{\circ} 96^{\prime} 30.51 \mathrm{LS} ; 1^{0} 3^{\circ} 46^{\prime} 58.75 \mathrm{BT}$ \\
\hline 8. & Pelawi & Buay Rawan & OKU Selatan & 415 & $04^{0} 69^{\prime} 57.50 \mathrm{LS} ; 104^{\circ} 02^{\prime} 54.57 \mathrm{BT}$ \\
\hline 9. & Atung Bungsu & Dempo Selatan & Pagaralam & 535 & $04^{\circ} 02^{\prime} 18.51 \mathrm{LS} ; 103^{\circ} 38^{\prime} 18.90 \mathrm{BT}$ \\
\hline 10. & Tanjung Baru Rawan & Buay Pemulang Ribu & Oku Selatan & 750 & $04^{\circ} 80^{\prime} 79.28 \mathrm{LS} ; 104^{\circ} 00^{\prime} 9237 \mathrm{BT}$ \\
\hline 11. & Bangun Rejo & Pagaralam Utara & Pagaralam & 811 & $04^{\circ} 02^{\prime} 27.27 \mathrm{LS} ; 103^{\circ} 22^{\prime} 71.14 \mathrm{BT}$ \\
\hline 12. & Pagaradin & Pagaralam Utara & Pagaralam & 954 & $04^{\circ} 05^{\prime} 32.56 \mathrm{LS} ; 103^{\circ} 20^{\prime} 04.04 \mathrm{BT}$ \\
\hline 13. & Bumi Agung & Pagaralam Utara & Pagaralam & 1010 & $04^{\circ} 04^{\prime} 70.00 \mathrm{LS} ; 103^{\circ} 18^{\prime} 62.92 \mathrm{BT}$ \\
\hline 14. & Bedeng Kresek & Pagaralam Utara & Pagaralam & 1028 & $04^{\circ} 00^{\prime} 34.83 \mathrm{LS} ; 103^{\circ} 21^{\prime} 27.05 \mathrm{BT}$ \\
\hline 15. & Kerinjing & Dempo Utara & Pagaralam & 1285 & $04^{\circ} 03^{\prime} 79.30 \mathrm{LS} ; 103^{\circ} 22^{\prime} 77.61 \mathrm{BT}$ \\
\hline
\end{tabular}
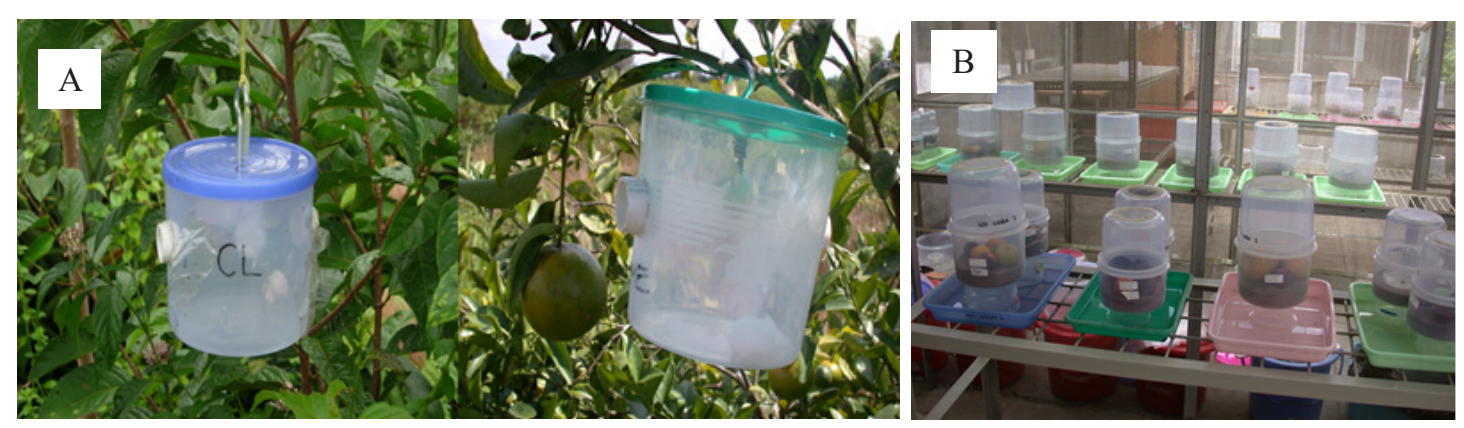

Gambar 1. A: pemasangan perangkap berisi atraktan cue lure dan metil eugenol; B: pemeliharaan buah terserang lalat buah di laboratorium. 


\section{Analisis data}

Data tentang spesies lalat buah dan tanaman inang disusun dalam bentuk tabulasi, dianalisis secara deskriptif dan disajikan dalam bentuk tabel, grafik, dan foto.

\section{HASIL}

\section{Keanekaragaman lalat buah di Sumatera Selatan}

Lalat buah yang tertangkap dengan menggunakan dua atraktan (ME dan CL) sebanyak 18 spesies. Jenis tanaman buah yang diamati sebanyak 24 jenis meliputi tanaman buah sayur dan buah konsumsi langsung (Tabel 2). Hasil pengamatan menunjukkan bahwa perangkap dengan menggunakan ME dapat menangkap 7 spesies lalat buah pada berbagai macam tanaman inang (Tabel 3). Alat perangkap yang menggunakan atraktan CL dapat menangkap 10 spesies lalat buah (Tabel 4). Hasil pengamatan menunjukkan bahwa ada beberapa spesies lalat buah yang hidup pada semua vegetasi tanaman yang diamati (nomor 1-24), seperti Bactrocera occipitalis, B. papayae, B. albistrigata, B. caudata, B. melastomatos, $B$. nigrotibialis, dan $B$. tau. Namun, terdapat juga lalat buah yang hanya ditemukan pada sedikit vegetasi, seperti $B$. atrifemur yang ditemukan pada 5 jenis vegetasi (pisang, pepaya, jambu air, nanas, dan mangga).

\section{Pola keberadaan lalat buah berdasarkan tanaman inang dan ketinggian lokasi}

Sebanyak 7 spesies muncul dari pemeliharaan buah di laboratorium, yaitu $B$. albistrigata, B. carambolae, B. fuscitibia, B. latifrons, B. occipitalis, B. papayae, dan Bactrocera sp. Spesies yang lain ditemukan melalui pemasangan atraktan ME sebanyak 7 spesies dan atraktan CL sebanyak 10 spesies. Ada 6 spesies lalat buah yang ditemukan dari koleksi buah maupun pemasangan perangkap, yaitu B. albistrigata, B. carambolae, B. fuscitibia, B.occipitalis, B. papayae, dan Bactrocera sp.

Tabel 2. Jenis tanaman buah yang diamati

\begin{tabular}{llllll}
\hline No. & Nama umum & Nama ilmiah & No. & Nama umum & Nama ilmiah \\
\hline 1 & Jeruk & Citrus sp. & 13 & Terong & Solanum melongena \\
2 & Sawo & Achras zapota & 14 & Cabe & Capsicum annumm \\
3 & Pisang & Musa paradisiaca & 15 & Alpukat & Persea americana \\
4 & Pepaya & Carica papayae & 16 & Nenas & Ananas comusus \\
5 & Jambu Bol & Syzygium malaccense & 17 & Salak & Salacca edulis \\
6 & Nangka & Artocarpus heterophyllus & 18 & Mangga & Mangifera indica \\
7 & Belimbing & Averhoa carambola & 19 & Kopi & Coffea sp. \\
8 & Jambu Air & Eugenia aquea & 20 & Lumai & Solanum nigricornis \\
9 & Jambu Biji & Psidium guajava & 21 & Kesemak & Diospyros kaki \\
10 & Belimbing Wuluh & Averhoa bilimbi & 22 & Kakao & Theobroma cacao \\
11 & Kedondong & Spondias dulcis & 23 & Mengkudu & Morinda citrifolia \\
12 & Tekokak & Solanum torvum & 24 & Mahkota Dewa & Phaleria macrocarpa \\
\hline
\end{tabular}

Tabel 3. Spesies lalat buah yang tertangkap menggunakan atraktan metil eugenol pada berbagai jenis tanaman inang. Kode tanaman inang berdasarkan kode pada Tabel 2

\begin{tabular}{ll}
\hline $\begin{array}{l}\text { Spesies lalat buah yang } \\
\text { tertangkap }\end{array}$ & Jenis tanaman inang \\
\hline $\begin{array}{l}\text { Bactrocera atrifemur } \\
\text { Bactrocera floresiae }\end{array}$ & $3,4,8,16,18$ \\
Bactrocera carambolae & $1,2,4,9,10,11,23$ \\
Bactrocera occipitalis & $1,2,3,4,5,6,7,7,8,9,10,11,12,13,14,15,16,17,18,19,20,21,22,23,24$ \\
Bactrocera papayae & $1,2,3,4,5,6,7,8,9,10,11,12,13,14,15,16,17,18,19,20,21,22,23,24$ \\
Bactrocera umbrosa & $1,2,3,4,5,6,7,8,9,10,11,12,13,14,15,16,17,18,19,20,21,22,23$ \\
Bactrocera sp. & $1,2,3,4,5,6,7,8,9,10,11,12,13,14,15,16,17,18,19,20,21,22,23$ \\
\hline
\end{tabular}


Tabel 4. Spesies lalat buah yang tertangkap oleh atraktan cue-lure pada berbagai jenis tanaman inang. Kode tanaman inang berdasarkan kode pada Tabel 2

\begin{tabular}{ll}
\hline $\begin{array}{l}\text { Spesies lalat buah yang } \\
\text { tertangkap }\end{array}$ & Jenis tanaman inang \\
\hline Bactrocera albistrigata & $1,2,3,4,5,6,7,8,9,10,11,12,13,14,15,16,17,18,19,20,21,22,23,24$ \\
Bactrocera ascitus & $1,2,3,7,13,15$ \\
Bactrocera caudata & $1,2,3,4,5,6,7,8,9,10,11,12,13,14,15,16,17,18,19,20,21,22,23,24$ \\
Bactrocera cilifera & $1,2,4,9,7,12,13,14,15,16$, \\
Bactrocera cucurbitae & $1,2,4,7,8,9,12,13,14,15,19,20,21,23$ \\
Bactrocera fuscitibia & $3,4,8,9,18,16$ \\
Bactrocera melastomatos & $1,2,3,4,5,6,7,8,9,10,11,12,13,14,15,16,17,18,19,20,21,22,23,24$ \\
Bactrocera nigrotibialis & $1,2,3,4,5,6,7,8,9,10,11,12,13,14,15,16,17,18,19,20,21,22,23,24$ \\
Bactrocera tau & $1,2,3,4,5,6,7,8,9,10,11,12,13,14,15,16,17,18,19,20,21,22,23,24$ \\
Dacus (Callantra) longicornis & $1,2,3,7,23$ \\
\hline
\end{tabular}

Hasil penelitian menunjukkan bahwa satu spesies lalat buah dapat menyerang lebih dari satu spesies tanaman. Dua spesies lalat buah ditemukan menyerang banyak jenis buah di berbagai ketinggian tempat di atas permukaan laut, yaitu B. carambolae dan B. papayae. B. carambolae menyerang 10 jenis tanaman inang, dan B. papayae menyerang 12 jenis tanaman inang (Tabel 5). Selain itu, satu spesies tanaman inang dapat diserang lebih dari satu spesies lalat buah. Hasil penelitian menunjukkan bahwa dalam satu tanaman dapat diserang oleh 1-5 spesies lalat buah. Artinya, satu spesies lalat buah itu memiliki banyak tanaman inang.

Sebagian besar lalat ditemukan di daerah dataran rendah $(0-100 \mathrm{~m} \mathrm{dpl})$. Buah yang didapatkan di dataran rendah dan dipelihara di laboratorium, menunjukkan hasil enam spesies, sedangkan secara khusus $B$. latrifons ditemukan dari buah yang diambil dari dataran tinggi, yaitu dari Famili Solanaceae (cabai, terong, lumai, kembang madira, dan tekokak) (Tabel 5). Tujuh spesies ditemukan pada daerah dataran rendah, menengah maupun tinggi, yaitu $B$. albistrigata, B. caudata, B. carambolae, B. melastomatos, $B$. occipitalis, B. papayae, dan B. tau. B. latrifons tidak ditemukan dari pemasangan perangkap baik ME maupun CL di dataran rendah dan dataran tinggi (Tabel 6).

Dari pemeliharaan berbagai jenis buah yang diambil di lapangan, terdapat enam spesies lalat buah yang berhasil diidentifikasi sampai spesies. Lalat buah tersebut adalah $B$. albistrigata,
B. carambolae, B. fuscitibia, B. latifrons, B. occipitalis, dan B. papayae (Gambar 2-7).

\section{PEMBAHASAN}

Dari pemasangan atraktan baik ME maupun CL menunjukkan bahwa terdapat 17 spesies yang ditemukan pada semua jenis vegetasi. Hal ini menunjukkan bahwa persebaran spesies tersebut sudah sangat luas, artinya spesies lalat buah tersebut memiliki kesukaan pada berbagai vegetasi tanaman, walaupun belum tentu spesies tersebut menyerang buah atau tanaman inang tersebut. Keberadaan lalat buah di berbagai vegetasi dapat saja menunjukkan bahwa lalat tersebut sedang melakukan pencarian inang (Uramoto et al. 2008). Kadang-kadang lalat buah jantan yang tertarik dan mengkonsumsi ME akan memancarkan kembali ke sekelilingnya sehingga dapat menarik lalat betina (Tan \& Nishida 2012; Tan \& Nishida 2014).

Pemasangan atraktan ME dapat memerangkap 7 spesies dan atraktan CL sebanyak 10 spesies (Tabel 3). Hal ini merupakan jumlah yang cukup banyak mengingat bahwa lokasi pengambilan contoh meliputi seluruh Provinsi Sumatera Selatan. Apabila dibandingkan dengan hasil penelitian yang dilakukan oleh Suputa et al. (2010), di Palembang hanya ditemukan sebanyak 2 spesies (B. papayae dan B. umbrosa) tertarik pada ME dan 4 spesies (B. melastomatos, B. albistrigata, B. caudata, dan B. cucurbitae) tertarik pada CL. Larasati et al. (2013) melaporkan di Kabupaten 
Tabel 5. Spesies lalat buah dan tanaman inang di berbagai ketinggian tempat di atas permukaan laut

\begin{tabular}{|c|c|c|c|c|}
\hline \multirow{2}{*}{ Spesies lalat buah } & \multirow{2}{*}{ Inang } & \multicolumn{3}{|c|}{ Ketinggian tempat (m dpl) } \\
\hline & & $0-100$ & $400-600$ & $750-1300$ \\
\hline \multirow[t]{4}{*}{ Bactrocera albistrigata } & Eugenia aquea (Jambu air) & + & - & + \\
\hline & Lansium domesticum (Duku) ${ }^{*}$ & + & - & - \\
\hline & Psidium guajava (Jambu biji) & + & + & 0 \\
\hline & Syzygium malaccense (Jambu bol)* & + & - & - \\
\hline \multirow[t]{10}{*}{ Bactrocera carambolae } & Achras zapota (Sawo)* & + & 0 & 0 \\
\hline & Averhoa bilimbi (Belimbing wuluh)* & + & - & - \\
\hline & Averhoa carambola (Belimbing) & + & + & + \\
\hline & Carica papaye (Рepaya) & + & 0 & + \\
\hline & Eugenia aquea (Jambu air) & + & - & 0 \\
\hline & Lansium domesticum (Duku)* & + & + & + \\
\hline & Mangifera indica (Mangga) & 0 & + & - \\
\hline & Phaleria macrocarpa (Mahkota dewa)* & + & 0 & - \\
\hline & Psidium guajava (Jambu biji) & + & + & + \\
\hline & Syzygium malaccense (Jambu bol)* & + & - & - \\
\hline Bactrocera fuscitibia ${ }^{\#}$ & Psidium guajava (Jambu biji) & + & 0 & 0 \\
\hline \multirow[t]{5}{*}{ Bactrocera latifrons ${ }^{\#}$} & Capsicum annuum (Cabai)* & 0 & 0 & + \\
\hline & Solanum melongena (Terong)* & 0 & + & + \\
\hline & Solanum nigricornis (Lumai)* & - & - & + \\
\hline & Solanum sp. (Kembang madira)* & - & - & + \\
\hline & Solanum torvum (Tekokak)* & - & + & + \\
\hline \multirow[t]{3}{*}{ Bactrocera occipitalis } & Averhoa carambola (Belimbing) & + & 0 & 0 \\
\hline & Eugenia aquea (Jambu air) & + & - & 0 \\
\hline & Phaleria macrocarpa (Mahkota dewa)* & + & 0 & - \\
\hline \multirow[t]{12}{*}{ Bactrocera papayae } & Averhoa carambola (Belimbing) & + & 0 & + \\
\hline & Achras zapota (Sawo)* & + & 0 & 0 \\
\hline & Capsicum annum (Cabai) & + & - & + \\
\hline & Capsicum frutescens (Cabai rawit)* & + & - & - \\
\hline & Carica papaye (Pepaya) & + & 0 & + \\
\hline & Citrus sp. (Jeruk)* & + & 0 & 0 \\
\hline & Eugenia aquea (Jambu air) & + & - & + \\
\hline & Musa paradisiaca (Pisang putri)* & + & - & - \\
\hline & Phaleria macrocarpa (Mahkota dewa)* & + & 0 & - \\
\hline & Psidium guajava (Jambu biji) & + & 0 & 0 \\
\hline & Solanum melongena (Terong)* & + & 0 & + \\
\hline & Spondias dulcis (Kedondong)* & + & - & 0 \\
\hline \multirow[t]{4}{*}{ Bactrocera sp. } & Achras zapota (Sawo)* & + & 0 & 0 \\
\hline & Carica papaye (Pepaya) & 0 & 0 & + \\
\hline & Psidium guajava (Jambu biji) & + & 0 & 0 \\
\hline & Solanum melongena (Terong)* & 0 & + & 0 \\
\hline
\end{tabular}

\#: spesies baru yang dilaporkan; *: inang baru yang dilaporkan; -: buah dipelihara, tidak muncul lalat buah; +: buah dipelihara, muncul lalat buah; 0 : buah tidak dipelihara, tidak muncul lalat buah.

Bogor dan sekitarnya berhasil diidentifikasi 5 spesies lalat buah yang terperangkap ME dan 11 spesies yang terperangkap CL. Dengan atraktan minyak selasih yang mengandung ME, Kardinan et al. (2020) berhasil memerangkap B. dorsalis dan B. umbrosus Fabricius yang didominasi oleh lalat jantan.

Dari ke 19 jenis buah-buahan itu ada 13 jenis yang sebarannya baru saat ini dilaporkan, ke 13 jenis buah-buahan itu, ialah belimbing wuluh, duku, jambu bol, jeruk, kembang madira, mahkota dewa, nangka, pisang putri, sawo, terong bulat, takokak, lumai, dan kedondong. Enam jenis buah yang dipantau dalam penelitian dan tidak diserang lalat buah, ialah buah alpukat, kopi, melastoma, mengkudu, nenas, dan salak. Buahbuahan tersebut tidak diserang oleh lalat buah, diduga karena sifat fisik buah yang memiliki kulit buah yang keras. Kulit buah yang keras tersebut menjadi penghambat imago lalat buah meletakkan 
Tabel 6. Spesies lalat buah terperangkap dari berbagai ketinggian tempat

\begin{tabular}{|c|c|c|c|c|}
\hline \multirow{2}{*}{ Spesies lalat buah } & \multicolumn{3}{|c|}{ Ketinggian tempat (m dpl) } & \multirow{2}{*}{ Atraktan } \\
\hline & $0-100$ & $400-600$ & $750-1300$ & \\
\hline Bactrocera albistrigata & + & + & + & CL \\
\hline Bacrocera ascitus & - & + & + & $\mathrm{CL}$ \\
\hline Bactrocera atrifemur & + & - & - & ME \\
\hline Bactrocera caudata & + & + & + & CL \\
\hline Bactrocera carambolae & + & + & + & ME \\
\hline Bactrocera cilifera & - & - & + & CL \\
\hline Bactrocera cucurbitae & + & - & + & CL \\
\hline Bactrocera floresiae & + & - & - & ME \\
\hline Bactrocera fuscitibia & + & - & - & $\mathrm{CL}$ \\
\hline Bactrocera latifrons & - & - & - & $\mathrm{ME} \& \mathrm{CL}$ \\
\hline Bactrocera melastomatos & + & + & + & CL \\
\hline Bactrocera nigrotibialis & + & - & + & $\mathrm{CL}$ \\
\hline Bactrocera occipitalis & + & + & + & $\mathrm{CL}$ \\
\hline Bactrocera papayae & + & + & + & ME \\
\hline Bactrocera tau & + & + & + & ME \\
\hline Bactrocera umbrosa & + & - & + & CL \\
\hline Bactrocera sp. & + & - & + & ME \\
\hline Dacus (Callantra) longicornis & + & - & - & ME \\
\hline
\end{tabular}

CL: cue-lure; ME: metil eugenol

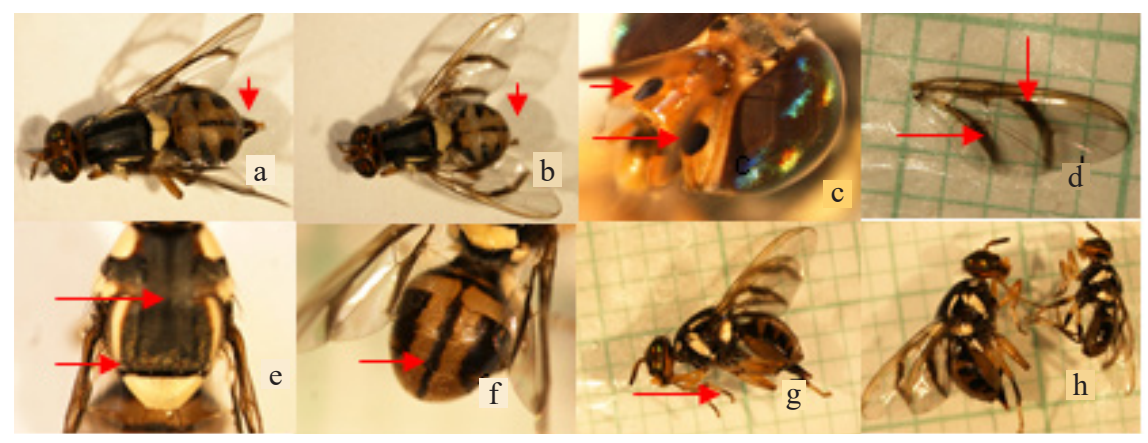

Gambar 2. Bactrocera albistrigata (de Meijere). a: imago betina ujung abdomen dengan ovipositor; b: imago jantan abdomen tanpa ovipositor; c: kepala ada sepasang spot hitam di wajah; d: sayap cubital streak lebar dan pita hitam memotong bagian tengah sayap menutup sel $\mathrm{r}-\mathrm{m}$ dan dm$\mathrm{cu}$; e: toraks skutum didominasi warna hitam dan pita kuning ujungnya meruncing berakhir sebelum inner alar setae; f: medial longitudinal lebar memotong terga III-V; g: tungkai fulvous h: ukuran jantan dan betina.

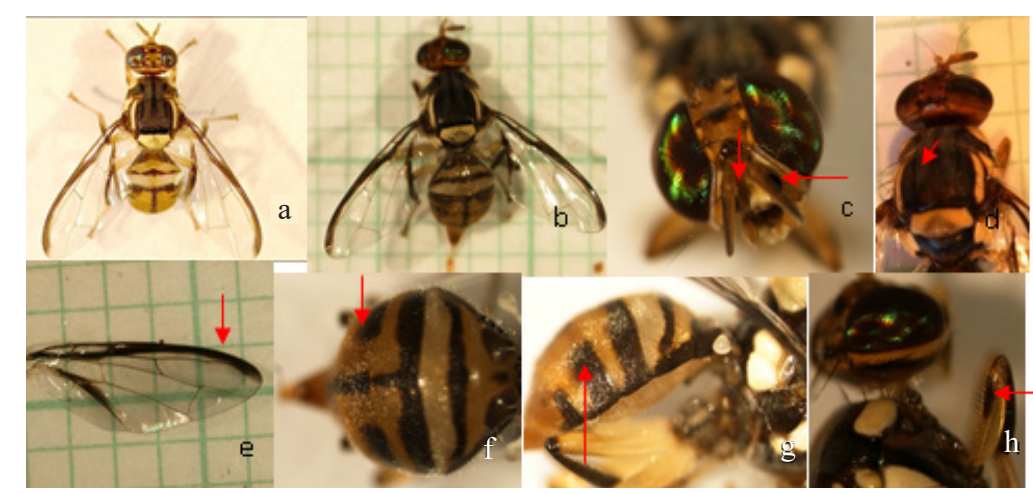

Gambar 3. Bactrocera carambolae Drew \&Hancock. a: imago jantan; b: imago betina; c: dua spot hitam di bagian wajah; d: toraks ada dua lateral postsutural vittae; e: sayap di bagian costal band overlapping di R 2+3; f: abdomen bentuk T berwarna hitam, medial longitudinal lebar; g: lateral margin meluas berbentuk segiempat; h: spot hitam di femur tungkai depan. 


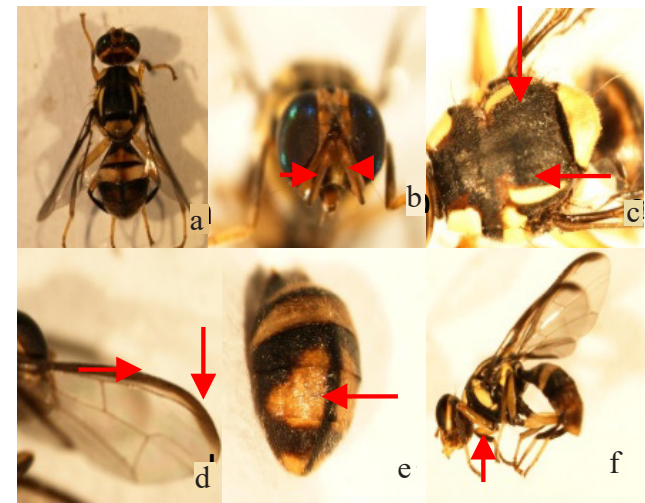

Gambar 4. Bactrocera fuscitibia Drew \& Hancock. a: imago jantan; b: sepasang spot hitam di wajah; c: skutum warna hitam, dua lateral postsutural vittae; d: sayap memiliki costal band overlapping di $\mathrm{R}$ 2+3; e: abdomen lateral margin terga III hitam meluas, medial longitudinal hitam dan lebar; f: tungkai, di femur depan sebagian atau seluruhnya berwarna kekuningan dan terdapat spot hitam.

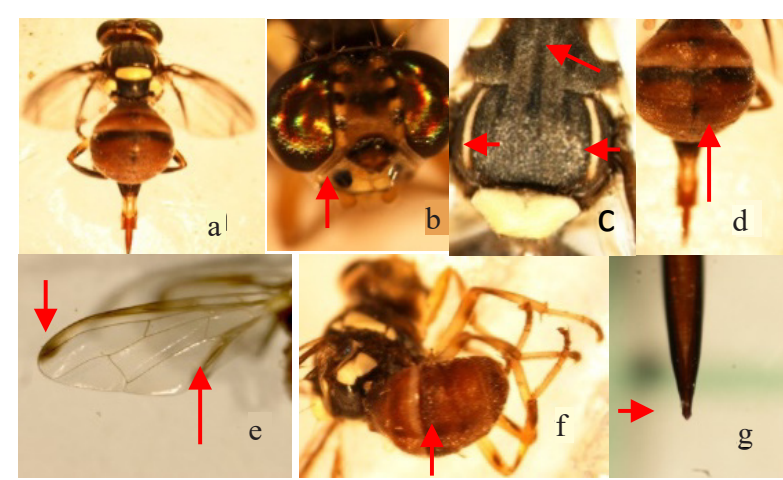

Gambar 5. Bactrocera latifrons (Hendel). a: imago betina; b: wajah memiliki dua spot hitam; c: toraks berwarna hitam, dua lateral postsutural vittae; d: abdomen didominasi warna kuning; e: sayap dengan costal band overlapping di R 2+3 memanjang dan membentuk spot di apex, cubital streak sempit; f: tungkai kekuningan terdapat spot gelap di bagian atas seluruh femur; g: aculeus berbentuk trilobes.

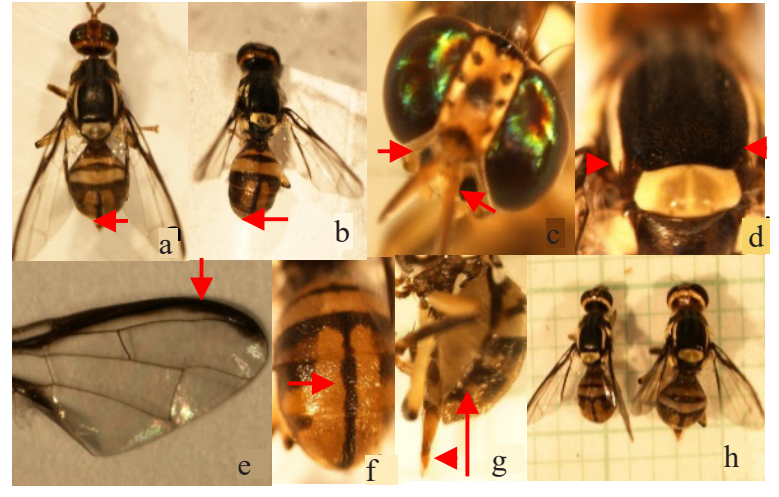

Gambar 6. Bactrocera occipitalis (Bezzi), a: imago betina ujung abdomen terdapat ovipositor; b: imago jantan ujung abdomen tanpa ovipositor; c: wajah memiliki dua spot hitam; d: toraks memiliki dua pita lateral postsutural vittae parallel sided berakhir di inner alar setae; e: sayap overlapping di $\mathrm{R} 2+3$; f: abdomen terga ke III-V terdapat medial longitudinal yang lebar; g: lateral margin hitam melebar, ovipositor memiliki ukuran aculeus 1,4-1,6 mm; h: ukuran jantan dan betina.

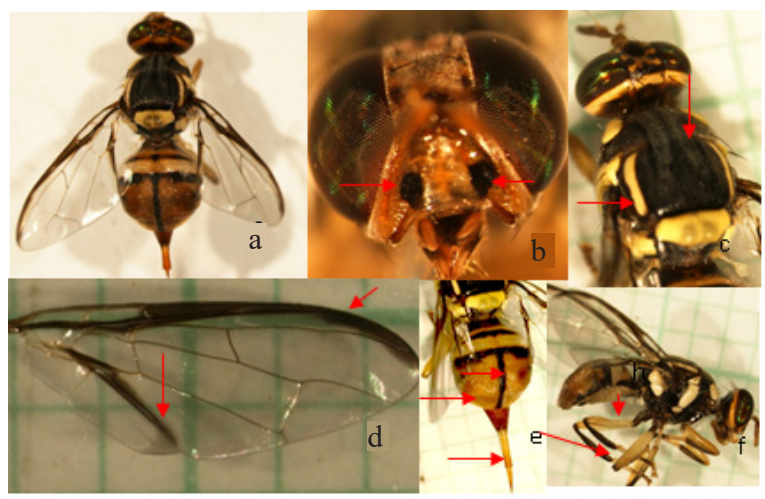

Gambar 7. Bactrocera papayae Drew \& Hancock. a: imago betina; b: dua spot hitam di wajah; c: toraks memiliki skutum berwarna hitam, terdapat dua pita lateral postsutural vittae; d: sayap memiliki costal band warna coklat yang sempit confluent di R 2+3, cubital streak sempit; e: abdomen terdapat bentuk $\mathrm{T}$ hitam memanjang melewati anterior terga III, medial longitudinal ukuran sedang memotong terga III-V, ovipositor betina ukuran panjang 1,5-2,1; f: kaki memiliki femur berwarna kekuningan, tibia depan dan belakang coklat gelap, basal tibia tengah kekuningan. 
telur karena sulit ditembus oleh ovipositor lalat buah (Dias et al. 2018).

Hasil penelitian menunjukkan bahwa jenis tumbuhan inang mempengaruhi spesies lalat buah. Lalat buah tertarik pada buah saat buah menjelang masak, jenis tanaman buah memiliki aroma atau ekstraksi ester dan asam organik yang semerbak saat buah menjelang masak. Warna kuning dan aroma zat yang terkandung dalam buah-buah yang masak mempengaruhi preferensi lalat buah terhadap jenis inang tertentu (Shahzadi et al. 2019; Pujiastuti et al. 2009).

Dari hasil pemeliharaan buah muncul 7 spesies, yakni $B$. albistrigata, $B$. carambolae, $B$. fuscitibia, B. occipitalis, B. latrifons, B. papaya, dan Bactrocera sp. Spesies lalat buah muncul dari berbagai jenis buah terserang yang dipelihara. Sebagai contoh, B. albistrigata muncul dari 4 jenis buah, yaitu jambu air, duku, jambu biji, dan jambu bol. Di antara ketujuh spesies tersebut, $B$. carambolae muncul dari 10 jenis tanaman inang dan B. papayae muncul dari 12 jenis tanaman inang. Hal ini sejalan dengan hasil penelitian Koswanudin et al. (2018) yang melaporkan bahwa B. carambolae menyukai buah belimbing malaya dan mangga manalagi. Jenis inang yang diserang oleh kedua spesies ini kebanyakan merupakan tanaman buah-buahan, banyaknya inang yang diserang oleh kedua spesies lalat buah tersebut diduga ada kaitannya dengan sifat polifag kedua spesies (Clarke 2016). Pujiastuti et al. (2009) melaporkan B. carambolae dan $B$. papayae menyerang buah-buah belimbing, mangga, dan pepaya di Sumatera Selatan. Hasil lebih lengkap dilaporkan oleh Susanto et al. (2020) pada tanaman mangga di sentra perkebunan mangga di Kecamatan Talun, Kabupaten Cirebon berhasil diidentifikasi 4 spesies lalat buah, yaitu $B$. dorsalis, B. carambolae, B. albistrigata, dan hibrid antara $B$. carambolae dan $B$. dorsalis. Kedua spesies yang diidentifikasi menyerang tanaman buah tersebut ( $B$. carambolae dan B. papayae) merupakan spesies lalat buah yang memiliki kisaran inang yang luas dan banyak menyerang buah-buah yang bernilai ekonomis. Pada tahun 2010, Suputa et al. (2010) melaporkan bahwa $B$. melastomatos ditemukan dari buah Melastoma malabatrichum (dengan nama lokal Karamunting). Spesies tersebut juga tertarik pada atraktan CL.
Ada hal yang sangat unik terjadi dalam penelitian, yaitu $B$. latifrons hanya ditemukan pada pemeliharaan buah koleksi saja, yaitu dari buah cabai, terong lumai, kembang madira, dan takokak. Tanaman-tanaman tersebut termasuk dalam Famili Solanaceae. Dari hasil pengamatan, pemeliharaan buah Famili Solanaceae muncul $B$. papayae dan B. latifrons. Hasil yang didapatkan tersebut sesuai dengan laporan Suputa et al. (2010) yang mengidentifikasi $B$. latrifons dari hasil pemeliharaan cabai merah (C. annuum), dan buah ciplukan (Physalis minima). Namun demikian, Herlinda et al. (2008) melaporkan hanya $B$. dorsalis yang muncul. Berarti ada penambahan data spesies yang menyerang pada buah tanaman Solanaceae. Di alam spesies B. latifrons tidak ditemukan baik dengan pemasangan atrakan ME maupun CL. Mwatawala et al. (2007) melaporkan hal yang sama, bahwa terdapat kekhususan pada B. latifrons. Spesies tersebut hanya muncul dari pemeliharaan African eggplant Solanum aethiopicum L. dan di alam lalat buah tersebut tertangkap pada campuran 3 jenis atraktan. Ada dugaan bahwa spesies tersebut akan tertarik pada atraktan diluar ME dan CL (McQuate et al. 2018). CABI (2020) menuliskan bahwa secara khusus nama umum dari B. latrifons adalah Solanum fruit fly mengingat spesies tersebut hanya menyerang tanaman Famili Solananeae (Mziray et al. 2010; Akhila \& Jiji 2015).

\section{KESIMPULAN}

Keanekaragaman spesies lalat buah di Sumatera Selatan mencakup 18 spesies dnegan jumlah tanaman inang sebanyak 24 jenis tanaman. Pola keberadaan lalat buah berdasarkan traktan yang dipergunakan menunjukkan bahwa atraktan CL dan ME masing-masing memerangkap 10 spesies dan 7 spesies. Satu spesies (B. latrifons) tidak dapat diperangkap baik dengan CL maupun ME. Hasil identifikasi lalat buah diperoleh sebanyak 17 spesies dengan perincian 10 spesies dari perangkap CL (B. albistrigata, $B$. ascitus, B. caudata, B. cilifera, B. cucurbitae, $B$. fuscitibia, B. melastomatos, B. nigrotibialis, $B$. tau, Dacus (Callantra) longicornis) dan 7 spesies dari perangkap ME (B. atrifemur, B. floresiae, 
B. carambolae, B. occipitalis, B. papayae, B. umbrosa, dan Bactrocera sp.). Dari sejumlah 18 spesies tersebut, 7 di antaranya diperoleh dari koleksi buah, yaitu $B$. albistrigata, B. carambolae, B. fuscitibia, B. occipitalis, B. latrifons, B. papayae, dan Bactrocera sp. Ketinggian lokasi daerah pengamatan, mempengaruhi keanekaragaman lalat buah. Semua spesies ditemukan di dataran rendah (0-100 m), kecuali B. ascitus, B. cilifera, dan B. latrifons. Di dataran sedang dan dataran tinggi, jumlah spesies lalat buah yang ditemukan lebih sedikit dibandingkan dengan di dataran rendah.

\section{DAFTAR PUSTAKA}

Akhila MU, Jiji T. 2015. Record of solanum fruit fly, Bactrocera latifrons (Hendel) (Diptera: Tephritidae) infesting solanaceous vegetables in Kerala. Current Biotica 9:78-81.

AQIS (Australian Quarantine and Inspection Service). 2008. Fruit Flies Indonesia: Their Identification. Pest Status dan Pest Management. Brisbane: International Center for The Manageme.

CABI. 2020. Bactrocera latifrons. (Solanum fruit fly). Tersedia pada: https://www.cabi.org/isc/ datasheet/8719 [Diakses tanggal 1 Juni 2020].

ClarkeAR. 2016. Why so many polyphagous fruitflies (Diptera: Tephritidae)? A further contribution to the 'generalism' debate. Biological Journal of the Linnean Society 120:245-257. doi: https:// doi.org/10.1111/bij. 12880 .

Dias NP, Navab DE, Garciaa MS, Silvac FF, Valgasb RA. 2018. Oviposition of fruit flies (Diptera: Tephritidae) and its relation with the pericarp of citrus fruits. Brazilian Journal of Biology 78: 443-448. doi: https://doi.org/10.1590/15196984.167661.

Drew RAI, Hancock DL. 1994. The Bactrocera dorsalis complex of fruit fly (Diptera:Tephritidae: Dacinae) in Asia. Bulletin of Entomological Research 2:1-68. doi: https://doi.org/10.1017/ S1367426900000278.

Drew RAI. 1989. The tropical fruit flies (Diptera: Tephritidae) of the Australian and Oceanian Regions. Di dalam: Memoirs of Queensland Museum. Vol. 26. hlm. 664-664. Brisbane: A-Queensland Goverment Project.

Herlinda S, Zuroaidah, Pujiastuti Y, Samad S, Adam T. 2008. Spesies lalat buah yang menyerang sayuran Solanaceae dan Cucurbitaceae di Sumatera Selatan. Jurnal Hortikultura 182:212220.
Kardinan A. 2019. Prospek insektisida nabati berbahan aktif metil eugenol (C12H24O2) sebagai pengendali hama lalat buah Bactrocera spp. (Diptera: Tephritidae). Perspektif 18:16-27. doi:https://doi.org/10.21082/psp.v18n1.2019.16-27.

Kardinan A, Bintoro MH, Syakir M, Amin AA. 2020. Penggunaan selasih dalam pengendalian hama lalat buah pada mangga. Jurnal Penelitian Tanaman Industri 15:101-109. doi: https://doi. org/10.21082/jlittri.v15n3.2009.101-109.

Koswanudin D, Basukriadi A, Samudra IM, Ubaidillah R. 2018. Host preference fruit flies Bactrocera carambolae (Drew \& Hancock) and Bactrocera dorsalis (Drew \& Hancock) (Diptera: Tephritidae) Jurnal Entomologi Indonesia 15:4049. doi: https://doi.org/10.5994/jei.15.1.40.

Larasati A, Hidayat P, Buchori D. 2013. Keanekaragaman dan persebaran lalat buah Tribe Dacini (Diptera: Tephritidae) di Kabupaten Bogor dan sekitarnya. Jurnal Entomologi Indonesia 10:51-59. doi: https://doi.org/10.5994/ jei.10.2.51.

Leblanc L, Aftab Hossain M, Khan SA, Jose MS, Rubinoff D. 2013. A preliminary survey of the fruit flies (Diptera: Tephritidae: Dacinae) of Bangladesh. Proceedings of the Hawaiian Entomological Society 45:51-58.

Liu X, Zhang L, Haack RA, Liu J, Ye H. 2019. A noteworthy step on a vast continent: new expansion records of the guava fruit fly, Bactrocera correcta (Bezzi 1916) (Diptera: Tephritidae), in mainland China. BioInvasions Records 8:530-539. doi: https://doi.org/10.3391/ bir.2019.8.3.08.

McQuate GT, Royer JE, Sylva CD. 2018. Field trapping Bactrocera latifrons (Diptera: Tephritidae) with select eugenol analogs that have been found to attract other 'non-responsive' fruit fly species. Insects 9:50. doi: https://doi. org/10.3390/insects9020050.

Mwatawala M, Meyer M De, White IM, Maerere A, Makundi RH. 2007. Detection of the solanum fruit fly, Bactrocera latifrons (Hendel) in Tanzania (Dipt., Tephritidae). Journal of Applied Entomology 131:501-503. doi: https://doi. org/10.1111/j.1439-0418.2007.01156.x.

Mziray HA, Rhodes H, Makundi, Mwatawala M, Maerere A, Meyer M De. 2010. Ecology and behavior host use of Bactrocera latifrons, a new invasive Tephritid species in Tanzania. Journal of Economic Entomology 103:70-76. doi: https:// doi.org/10.1603/EC09212.

Pujiastuti Y, Kartini L, Irsan C, Herlinda S, Adam T, Thalib R. 2009. Variasi jenis tanaman buah 
sebagai inang lalat buah (Diptera: Tephritidae) pada berbagai ketinggian tempat di Sumatera Selatan. Jurnal Agripeat 10:58-64.

Shahzadi K, Khan MA, Gul T, Ahmad T, Aslam F, Ishfaq M, Aslam I. 2019. Host preference of Bactrocera cucurbitae (Diptera: Tephritidae). Acta Scientific Agriculture 3:80-83. doi: https:// doi.org/10.31080/ASAG.2019.03.0689.

Shelly TE, Epsky N, Jang EB, Reyes-Flores J, Vargas RI. 2014. Trapping and the detection, control, and regulation of Tephritid fruit flies. Dordrecht: Springer. doi: https://doi.org/10.1007/978-94017-9193-9.

Shelly TE. 2010. Capture of Bactrocera Males (Diptera: Tephritidae) in Parapheromone-Baited Traps: A Comparison of Liquid versus Solid Formulation. Proceedings of the Hawaiian Entomological Society 42:1-8.

Siwi SS, Hidayat P, Suputa. 2006. Taxonomi dan Bioekologi Lalat Buah Penting di Indonesia (Diptera: Tephritidae). Bogor: Kerjasama Balai Besar Penelitian dan Pengembangan Bioteknologi dan Sumberdaya Genetik Pertanian.

Sohrab, Prasad CS, Hasan W. 2018. Study on the biology and life cycle of cucurbit fruit fly, Bactrocera cucurbitae (Coquillett). Journal of Pharmacognosy and Phytochemistry 2018:223226.

Suputa, Trisyono YA, Martono E, Siwi SS. 2010. Update on the host range of different species of fruit flies in Indonesia. Jurnal Perlindungan Tanaman Indonesia 16:62-75.

Suputa, Cahyanti, Kustaryati A, Railan M, Issusilaningtyas, Taufiq A. 2006. Pedoman Identifikasi Lalat Buah (Diptera: Tephritidae). Yogyakarta: Universitas Gadjah Mada.

Susanto A, Djaya L, Roziana E. 2020. Diversity of Bactrocera spp. on some mango varieties at Kecamatan Talun, Kabupaten Cirebon. Second International Conference on Sustainable Agriculture IOP Conf. Series: Earth and Environmental Science 458:012042. doi: https:// doi.org/10.1088/1755-1315/458/1/012042.
Tan KH, Nishida R, 2012. Methyl eugenol: its occurrence, distribution, and role in nature, especially in relation to insect behavior and pollination. Journal of Insect Science 12:56. doi: https://doi.org/10.1673/031.012.5601.

Tan KH, Nishida R, Jang EB, Shelly TE. 2014 Pheromones, male lures, and trapping of tephritid fruit flies. Di dalam: Shelly TE, Epsky N, Jang EB, Flores-Reyes J, Vargas RI (Eds), Trapping and the Detection, Control, and Regulation of Tephritid Fruit Flies. hlm.15-74. New York: Springer. doi: https://doi.org/10.1007/978-94017-9193-9_2.

Tan KH, Nishida R. 2014. Sex pheromone and mating competition after methyl eugenol consumption in the Bactrocera dorsalis complex. Di dalam: McPheron BA, Steck GJ (Eds.), Fruit Fly Pests-A World Assessment of Their Biology and Management. Beach, Florida: St Lucia Press, Delray.

Uramoto, Martins DS, Zucchi RA. 2008. Fruit flies (Diptera: Tephritidae) and their associations with native host plants in a remnant area of the highly endangered Atlantic Rain Forest in the State of Esp1'rito Santo, Brazil K. Bulletin of Entomological Research 98:457-466. doi: https://doi.org/10.1017/S0007485308005774.

Vargas RI, Piñero JC, Leblanc L. 2015. An overview of pest species of Bactrocera fruit flies (Diptera: Tephritidae) and the integration of biopesticides with other biological approaches for their management with a focus on the Pacific Region. Insects 6:297-318. doi: https://doi.org/10.3390/ insects6020297.

Vargas RI, Walsh WA, Kanehisa D, Stark JD, Nishida T. 2000. Comparative demography of three Hawaiian fruit flies (Diptera: Tephritidae) at alternating temperatures. Ecology and Population Biology 93:75-81. doi: https://doi. org/10.1603/0013-8746(2000)093[0075:CDOT $\mathrm{HF}] 2.0 . \mathrm{CO} ; 2$. 